\title{
Updates in Knee Joint Osteoarthritis
}

\author{
Alaa Ali M. Elzohry MD*1, Mohammed Farghaly Abd Elhamed MSc ${ }^{2}$, Bahaa Gamal Saad MSc ${ }^{2}$ \\ ${ }^{1}$ Lecturer of Anesthesia, Intensive care and Pain management South Egypt Cancer Institute Assiut University \\ ${ }^{2}$ Assistant Lecturer of Anesthesia, Intensive care and Pain management South Egypt Cancer Institute Assiut \\ University
}

*Corresponding Author: Alaa Ali M. Elzohry, Lecturer of Anesthesia, Intensive care and Pain management South Egypt Cancer Institute Assiut University, Egypt.Email: alaa.zohiry@hotmail.com

\begin{abstract}
Background: Osteoarthritis (OA) of knee is one of the most common debilitating conditions associated with pain and limitation in daily living activities which negatively affect quality-of-life. It is a disease of the entire joint, involving not only the joint lining but also cartilage, ligaments, and bone. It is characterized by breakdown of the cartilage, bony changes of the joints, deterioration of tendons and ligaments, and various degrees of inflammation of the synovium.
\end{abstract}

Aim of the Work: To discuss the incidence and updates in Pathophysiology of Osteoarthritis (OA) of knee and demonstrate updates in management to solve this problem.

Study Design: Narrative review article.

Conclusion: The current review revealed that Osteoarthritis $(O A)$ of knee joint has multi mechanism and increases the risk of complications bed redden as such, accounts for burden on economics budget.

Keywords: Osteoarthritis - knee joint - chronic pain management-VAS score.

\section{INTRODUCTION}

Osteoarthritis (OA) of knee is one of the most common debilitating conditions associated with pain and limitation in daily living activities which negatively affect quality-of-life. It is the most common form of joint disease, and among the top 10 causes of disability worldwide (1). Osteoarthritis is a degenerative disease characterized by joint pain, tenderness, stiffness, joint swelling, restricted movement and joint deformities (2).

Osteoarthritis (OA) refers to a clinical syndrome of joint pain with multifactorial pathology that is characterized by the gradual loss of articular cartilage, osteophyte formation, sub-chondral bone remodeling, and inflammation of the joint (3). It is a disease of the entire joint, involving not only the joint lining but also cartilage, ligaments, and bone. It is characterized by breakdown of the cartilage, bony changes of the joints, deterioration of tendons and ligaments, and various degrees of inflammation of the synovium (4).

Scott and Kowalczyk reported that a cohort study found that radiologic features of knee osteoarthritis were very common in adults: $13 \%$ of women 45-65 years of age (an incidence of $3 \%$ per year). Osteoarthritis commonly affects middle age to elderly population. Investigators have theorized the increase in osteoarthritis in women during menopause may partially be attributed to the hormonal factors (5).

In recent years, an increasing number of patients are being diagnosed with osteoarthritis, which has a notable impact on human health $(6,7)$. With aging of the population and increasing obesity, $\mathrm{OA}$ arises as a major public health problem and an important financial burden for the global economy.

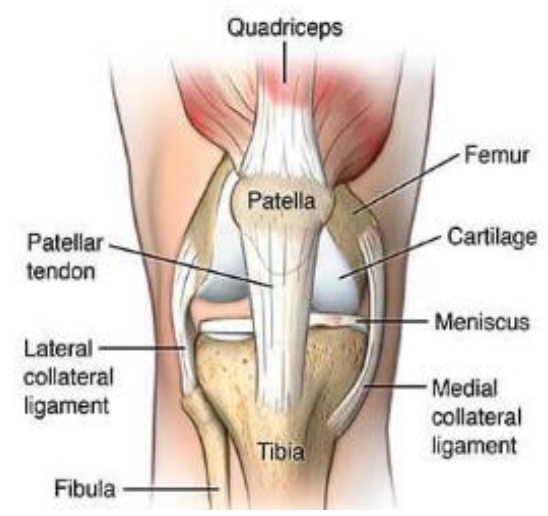




\section{PAThophysiology AND CAUSES OF OA}

The causes of osteoarthritis are complex, and the pathogenesis related to this disease is not well understood (8). Osteoarthritis is divided into primary and secondary osteoarthritis according to the presence of local and systemic risk factors (9). Osteoarthritis is frequently diagnosed as rheumatoid arthritis or ankylosing spondylitis in clinical differential diagnosis. It is the most common disease of arthritis and can occur together with other types of arthritis (10).
The differential diagnoses of knee chronic pain and osteoarthritis include: conditions involving soft tissue of knee such as bursitis, iliotibial band syndrome, ligamentous instability (medial and lateral collateral ligaments), meniscal pathology; other forms of arthritis like gout and pseudogout, rheumatoid arthritis and septic arthritis; referred pain from neuropathy or radiculopathy; and other diagnoses such as avascular necrosis, patellofemoral pain syndrome and tumor. (11, 12)

\section{Diagnostic criteria for osteoarthritis have been developed by the American College of Rheumatology. These criteria are outlines in Box 1}

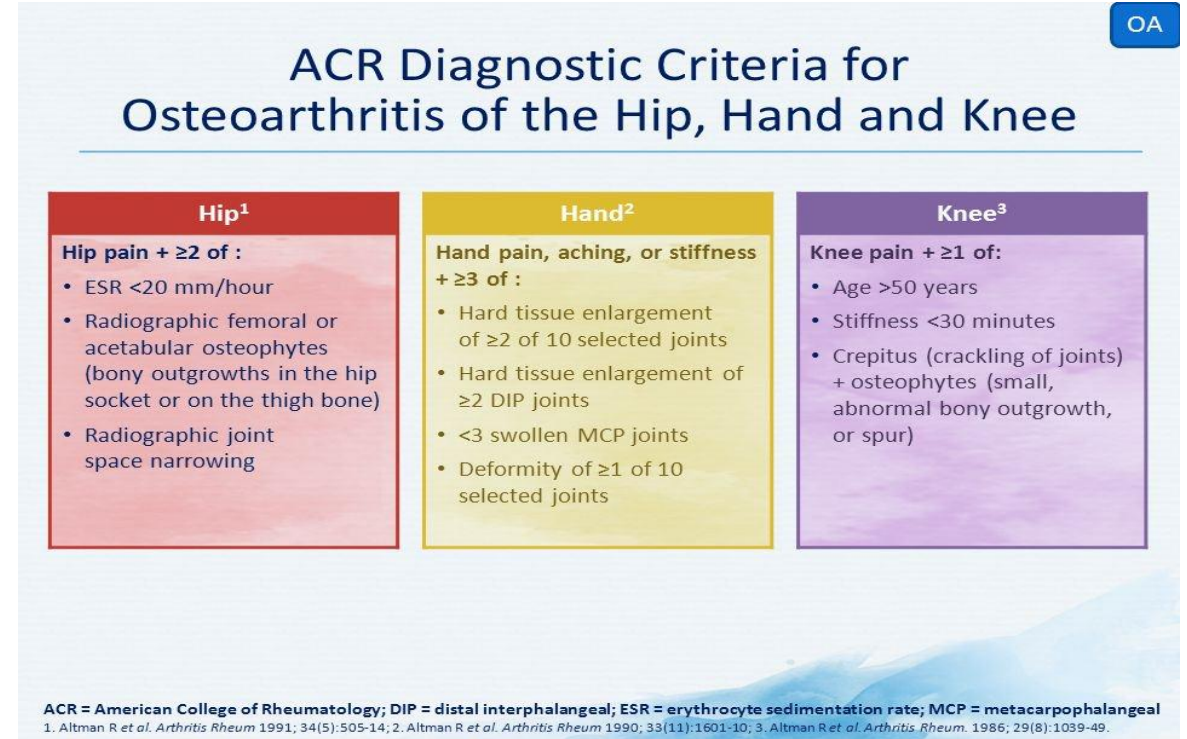

Another classification of knee osteoarthritis is Kellgren and Lawrence grading scale. It is based on radiological imaging and consists of different grades:

Grade 1: doubtful narrowing of joint space and possible osteophyte lipping;

Grade 2: definite osteophytes and possible narrowing of joint space;
Grade 3: moderate multiple osteophytes, definite narrowing of joint space and some sclerosis and possible deformity of bone ends; and

Grade 4: large osteophytes, marked narrowing of joint space, severe sclerosis and definite deformity of bone ends (14).

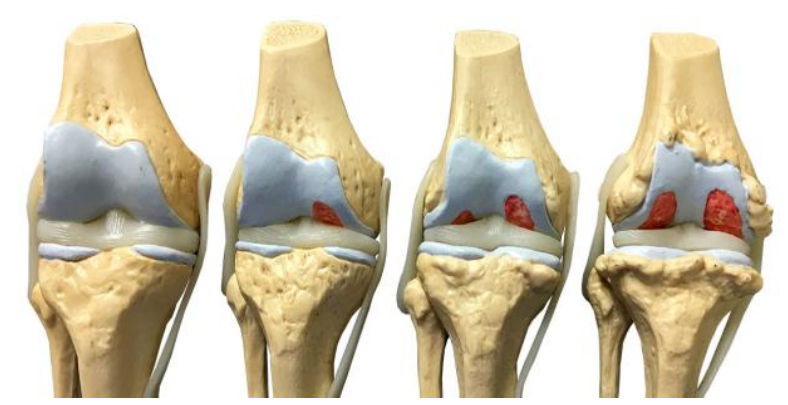

Criteria for diagnosis of knee osteoarthritis: $(15,16,17)$.

Clinical criteria: Age older than 50 years -Bony enlargement-Bony tenderness -Crepitus-No palpable warmth-Stiffness for $<30$ minutes.

Laboratory criteria: Erythrocyte sedimentation rate $\quad<40 \quad \mathrm{~mm} /$ hour-Rheumatoid factor
$<1$ :40-Synovial fluid analysis: clear, viscous, white blood cell count $<2,000 / \mu \mathrm{L}(2.00 \times 109$ per L)

Radiographic criteria: Presence of osteophytes. the next figure. 
Previous studies have indicated that agents targeting rheumatoid arthritis are relatively ineffective at present (18). Therefore, there is an urgent requirement for more efficient treatments for osteoarthritis with minimal side effects (19). To date, there is no effective cure for OA. Main

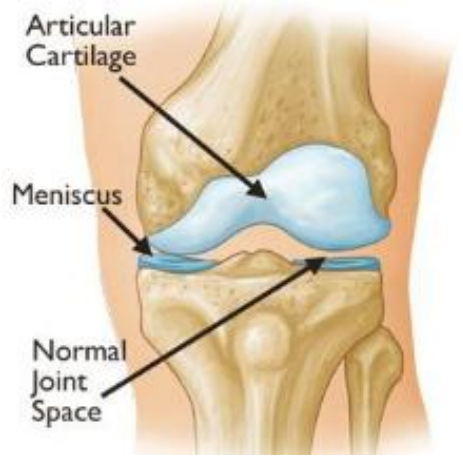

\section{Treatment OF OA}

In recent years, non-surgical treatments for knee osteoarthritis have become more widely used, such as PRP, corticosteroid injection and hyaluronic acid (21).

As regards conservative treatment for OA knee, various treatment modalities are recommended by clinical guidelines. Although different kinds of nonsurgical options are currently available for the treatment of knee joint osteoarthritis, they are mainly aimed at the symptomatic relief, but not joint cartilage regeneration (22-23).

The non pharmacological modalities include patient education, exercises and self management, lifestyle modifications such as dieting and weight reduction, walking supports (canes/crutches), bracing, shoe and insole modification, local hot/cold applications, acupuncture, and electromagnetic therapy.

Physical therapy is generally used, with exercises to maintain range of motion and strength. goals are to reduce pain, rigidity and swelling, and to improve function on the short term. On the long-term, the objectives are to reduce joint damage and to decrease destruction of the joint. (20)

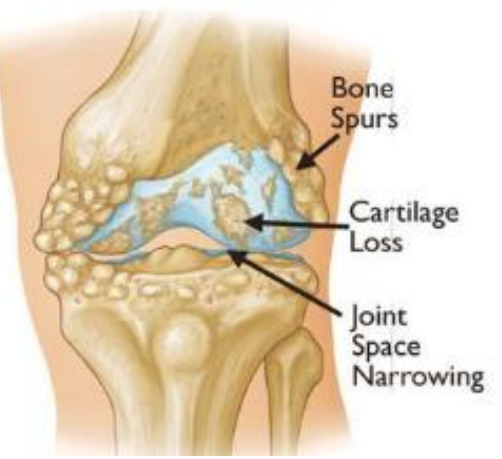

Pharmacologic therapies can be in the form of analgesics (paracetamol), NSAIDs, opioids, and slow-acting so-called nutraceuticals (glucosamine and chondroitin sulfate). If orally administered drugs are ineffective (24).

Intra-articular injections with corticosteroids seem to be safe. (25) More than one clinical guidelines reported high recommendations that these injections reduce pain for short term, especially if accompanied by effusion. $(26,27)$

Glucosamine is one of the building blocks of cartilage, which can be taken as a tablet as a supplement to the diet, or sometimes as an injection. (28) The clinical guidelines of the American Academy of Orthopedic Surgeons) reported strong recommendation of not prescribing glucosamine for symptomatic patients while other three guidelines (29-37) stated fairly low level strength of recommendation for conditional use or even uncertainty about it.

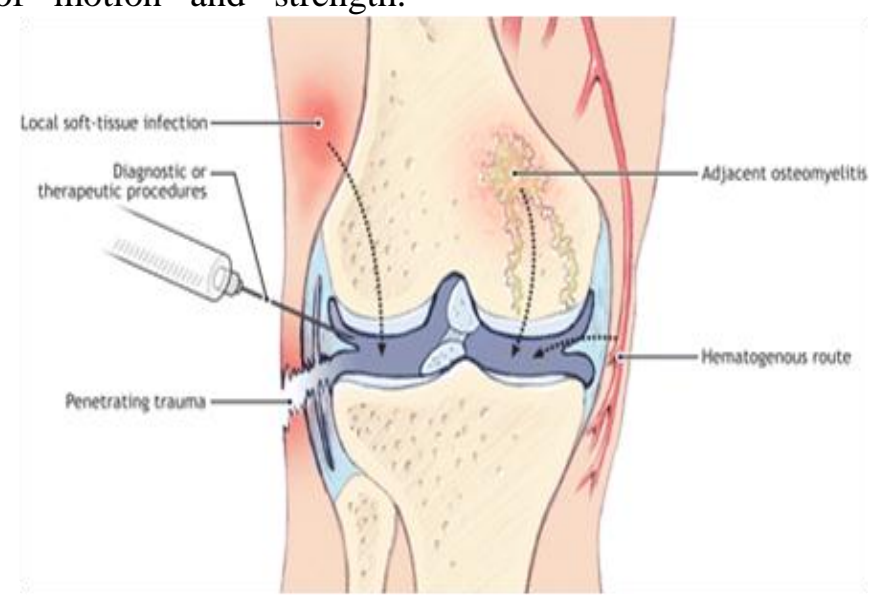

4. MECHANISM OF ACTION OF PLATELET RICH PLASMA

Autologous platelet concentrate suspended in plasma, also known as PRP, can be prepared from samples of centrifuged autologous blood. Exposure to a solution of thrombin and calcium chloride degranulates platelets, results in the formation of platelet gel and this stimulate the 
release of growth factors and bioactive molecules.(38) Therefore, platelets actively participate in healing processes by delivering a broad spectrum of growth factors (insulin- like growth factor, transforming growth factor $b^{-}$I, platelet ${ }^{-}$derived growth factor, and many others) and other active molecules (e.g., arachidonic acid metabolites, cytokines, chemokines, ascorbic acid, extracellular matrix proteins, and nucleotides) to the injured site(39).These factors altogether contribute to comprehensive roles of PRP, including anti-inflammation, angiogenesis, chondrogenesis, chondrocyte proliferation, bone remodeling, coagulation, and cell differentiation and this, in turn, reduces inflammation, pain \& can then be used as an adjunct to surgery with the intent of promoting hemostasis and accelerating healing (40).

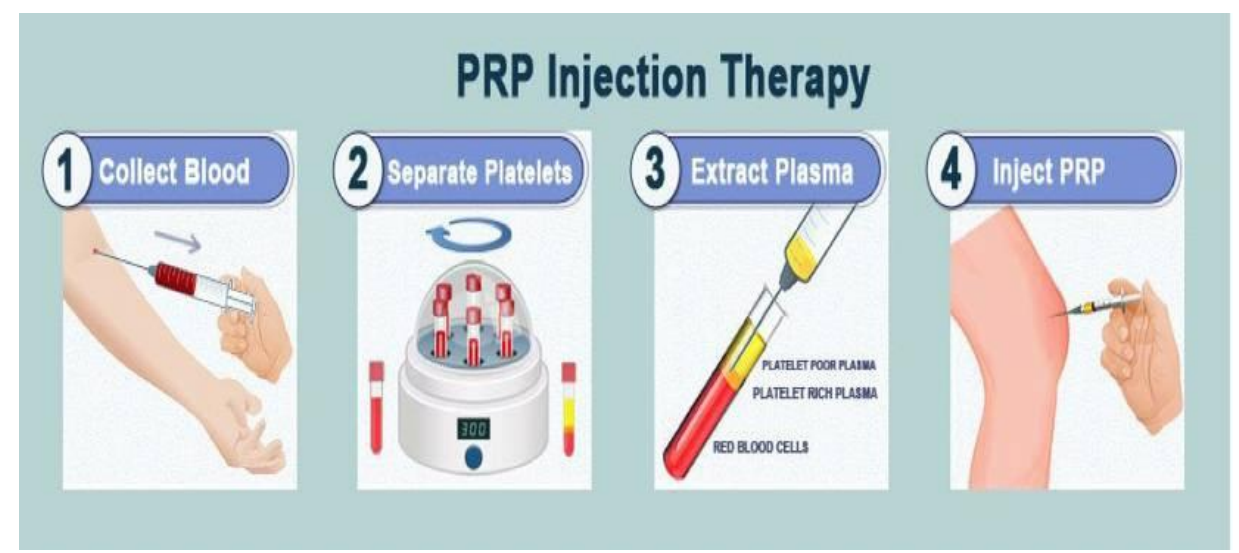

Use of platelet-rich plasma is considered experimental / investigational for all orthopedic indications. This includes, but is not limited to, use in the following situations:

A. Primary use (injection) for the following conditions (41-44):

1) Achilles tendinopathy

2) Lateral epicondylitis

3) Osteochondral lesions

4) Osteoarthritis

5) Plantar fasciitis

B. Adjunctive use in the following surgical procedures:

1) Anterior cruciate ligament reconstruction

2) Hip fracture

3) Long-bone nonunion

4) Patellar tendon repair

5) Rotator cuff repair

6) Spinal fusion

7) Subacromial decompression surgery

8) Total knee arthroplasty.

\section{CONCLUSION}

By reviewing current literature and our own experience, we feel that IA injections of HA, PRP, and corticosteroids given together for knee $\mathrm{OA}$ are an effective non-operative modality of treatment. In combination, they seem to have better efficacy than any of them given alone. These injections are clinically safe and have promising and very positive effects for patient satisfaction. When the heterogeneity of $\mathrm{OA}$ is considered, it is difficult to categorize which patients and what level of disease would be ideal indications for IA injections.

\section{REFERENCES}

[1] Neogi T. The epidemiology and impact of pain in osteoarthritis. Osteoarthritis Cartilage 2013; 21:1145-53.

[2] Onuora S: Osteoarthritis: Molecular imaging detects activated macrophages. Nat Rev Rheumatol 12: 313, 2016.

[3] Srikulmontree T. Osteoarthritis [Internet]. 2012 [updated 2012; cited 2012 Dec 03].

[4] Scott D, Kowalczyk A. Osteoarthritis of the knee. Am Fam Physician. 2008;77:1149-50

[5] Ma YW, Jiang DL, Zhang D, Wang XB and Yu XT: Radial extracorporeal shock wave therapy in a person with advanced osteonecrosis of the femoral head. Am J Phys Med Rehabil 95: e133-e139, 2016.

[6] Meheux CJ, McCulloch PC, Lintner DM, Varner KE and Harris JD: Efficacy of intra-articular platelet-rich plasma injections in knee osteoarthritis: A systematic review. Arthroscopy 32: 495-505, 2016.

[7] Lee GW, Park KS, Kim DY, Lee YM, Eshnazarov KE and Yoon TR: Results of total hip arthroplasty after core decompression with tantalum rod for osteonecrosis of the femoral head. Clin Orthop Surg 8: 38-44, 2016.

[8] Roemer FW, Kwoh CK, Hannon MJ, Hunter DJ, Eckstein F, Grago J, Boudreau RM, Englund M and Guermazi A: Partial meniscectomy is 
associated with increased risk of incident radiographic osteoarthritis and worsening cartilage damage in the following year. Eur Radiol 27: 404-413, 2017.

[9] Tang H, He S, Zhang X, Luo S, Zhang B, Duan $\mathrm{X}$, Zhang Z, Wang W, Wang Y and Sun Y: A network pharmacology approach to uncover the pharmacological mechanism of XuanHuSuo powder on osteoarthritis. Evid Based Complement Alternat Med 2016: 3246946, 2016.

[10] Poquet N, Williams M and Bennell KL: Exercise for Osteoarthritis of the Hip. Phys Ther 96: 1689-1694, 2016.

[11] Zhang W, Doherty M, Peat G, Bierma-Zeinstra MA, Arden NK, Bresnihan B, et al. EULAR evidence-based recommendations for the diagnosis of knee osteoarthritis. Ann Rheum Dis. 2010;69:483 9.

[12] Vicenzino B, Souvlis T, Wright A. Musculoskeletal pain. In: Strong J, Unruh AM, Wright A, Baxter GD, editors.Pain: a textboot for therapists. Edinburgh. Churchill Livingstone; 2002.23.Cleland JA, Koppenhaver S. Netter's orthopaedic clinical examination. 2nd ed. Philadelphia: Saunders; 2011

[13] Altman R, Asch E, Bloch D, Bole G, Borenstein $\mathrm{D}$, Brandt $\mathrm{K}$, et al. Development of criteria for the classification and reporting of osteoarthritis. Classification of osteoarthritis of the knee. Diagnostic and Therapeutic Criteria Committee of the American Rheumatism Association. Arthritis Rheum. 1986;29:1039-49

[14] Ringdahl E, Pandit S. Treatment of knee osteoarthritis. Am Fam Physician. 2011;83:1287-92.25. Kellgren JH, Lawrence JS. Radiological assessment of osteo-arthrosis. Ann Rheum Dis. 1957;16:494-502.

[15] Ringdahl E, Pandit S. Treatment of knee osteoarthritis. Am Fam Physician. 2011;83:1287-92.25.Kellgren JH, Lawrence JS. Radiological assessment of osteo-arthrosis. Ann Rheum Dis. 1957;16:494-502.26.

[16] Schiphof D, Boers M, Bierma-Zeinstra SM. Differences in descriptions of Kellgren and Lawrence grades of knee osteoarthritis. Ann Rheum Dis. 2008;67:1034-6.27.

[17] Altman R, Asch E, Bloch D, Bole G, Borenstein $\mathrm{D}$, Brandt K, et al. Development of criteria for the classification and reporting of osteoarthritis. Classification of osteoarthritis of the knee. Diagnostic and Therapeutic Criteria Committee of the American Rheumatism Association. Arthritis Rheum. 1986;29:1039-49

[18] Maricar N, Callaghan MJ, Parkes MJ, Felson DT and O'Neill TW: Clinical assessment of effusion in knee osteoarthritis-A systematic review. Semin Arthritis Rheum 45: 556-563, 2016.

[19] Beumer L, Wong J, Warden SJ, Kemp JL, Foster $\mathrm{P}$ and Crossley KM: Effects of exercise and manual therapy on pain associated with hip osteoarthritis: A systematic review and meta-analysis. Br J Sports Med 50: 458-463, 2016.

[20] Cuadros MEF, Moro OSP, Florin MJA, et al. Ozone improves pain relief function and quality of life in patients with knee osteoarthritis: A prospective quasi-experimental before-after study. Middle East Journal of Rehabilitation and Health. 2017;4(1):e41821.

[21] Jang SJ, Kim JD and Cha SS: Platelet-rich plasma (PRP) injections as an effective treatment for early osteoarthritis. Eur J Orthop Surg Traumatol 23: 573-580, 2013

[22] Jevsevar DS, Brown GA, Jones DL, Matzkin EG, Manner PA, Mooar P, Schousboe JT, Stovitz S, Sanders JO, Bozic KJ, et al. The American Academy of Orthopaedic Surgeons evidence-based guideline on: treatment of osteoarthritis of the knee, 2nd edition. J Bone Joint Surg Am. 2013;95:1885-1886.

[23] Handl M, Amler E, Bräun K, Holzheu J, Trc T, Imhoff A B, et al. Positive effect of oral supplementation with glycosaminoglycans and antioxidants on the regeneration of osteochondral defects in the knee joint. Physiol Res 2007; 56:243Y9.

[24] Zhang W, Nuki G, Moskowitz RW, Abramson S, Altman RD, Arden NK, Bierma-Zeinstra S, Brandt KD, Croft P, Doherty M, et al. OARSI recommendations for the management of hip and knee osteoarthritis: part III: Changes in evidence following systematic cumulative update of research published through January 2009. Osteoarthritis Cartilage. 2010;18:476499.

[25] Reid MC, Shengelia R, Parker SJ. Pharmacologic management of osteoarthritisrelated pain in older adults. Am $\mathbf{J}$ Nurs. 2012;112:S38-S43

[26] Jordan KM, Arden NK, Doherty M, Bannwarth B, Bijlsma JW, Dieppe P, et al. EULAR Recommendations 2003: an evidence based approach to the management of knee osteoarthritis: report of a task force of the standing committee for international clinical studies including trials (ESCISIT). Ann Rheum Dis. 2003;62:1145-55.

[27] Zhang W, Moskowitz RW, Nuki G, Abramson $\mathrm{S}$, Altman RD, Arden $\mathrm{N}$, et al. OARSI recommendations for the management of hip and knee osteoarthritis, Part II: OARSI evidence-based, expert consensus guidelines. Osteoarthr Cartil. 2008;16:137-62

[28] Towheed T, Maxwell L, P. AT, Shea B, Houpt $\mathrm{JB}$, Welch V, et al. Glucosamine therapy for treating osteoarthritis (review). Cochrane Database Syst Rev [Internet]. 2009. Available from: http://www.mrw.interscience.wiley.Com /cochrane/clsysrev/articles/CD002946/frame. html. doi: 10.1002/14651858.CD002946. pub2 
[29] Zhang W, Moskowitz RW, Nuki G, Abramson $\mathrm{S}$, Altman RD, Arden $\mathrm{N}$, et al. OARSI recommendations for the management of hip and knee osteoarthritis, Part II: OARSI evidence-based, expert consensus guidelines. Osteoarthr Cartil. 2008;16:137-62.

[30] Hochberg MC, Altman RD, April KT, Benkhalti M, Guyatt G, McGowan J, et al. American College of Rheumatology 2012 recommendations for the use of nonpharmacologic and pharmacologic therapies in osteoarthritis of the hand, hip, and knee. Arthritis Care Res (Hoboken). 2012;64:455-74

[31] Pierce TP, Jauregui JJ, Elmallah RK, Lavernia CJ, Mont MA and Nace J: A current review of core decompression in the treatment of osteonecrosis of the femoral head. Curr Rev Musculoskelet Med 8: 228-232, 2015.

[32] Ulrich-Vinther M, Maloney MD, Schwarz EM, Rosier R, O'Keefe RJ. Articular cartilage biology. J Am Acd Orthop Surg 2003; 11:421Y30.

[33] Pietrzak WS, Eppley BL. Platelet rich plasma: Biology and new technology. J Craniofac Surg 2005;16:1043-54.

[34] Werner S, Grose R. Regulation of wound healing by growth factors and cytokines. Physiol Rev 2003;83:835-70.

[35] Sampson S, Gerhardt M, Mandelaum B. Platelet rich plasma injection grafts for musculoskeletal injuries: A review. Curr Rev Musculoskelet Med2008; 1:165-74.

[36] Hunziker EB, Driesang IM, Morris EA. Chondrogenesis in cartilage repair is induced by members of the transforming growth factor-beta superfamily. Clin Orthop Relat Res 2001;391(suppl):S171-81.
[37] Anitua E, Sánchez M, Nurden AT, Zalduendo MM, de la Fuente M, Azofra J, et al. Platelet released growth factors enhance the secretion of hyaluronic acid and induce hepatocyte growth factor production by synovial fibroblasts from arthritic patients. Rheumatology 2007; 46:176972.

[38] Anitua E, Andia I, Ardanza B, Nurden P, Nurden AT. Autologous platelets as a source of proteins for healing and tissue regeneration. Thromb Haemost 2004;91:4-15.

[39] Pietrzak WS, Eppley BL. Platelet rich plasma: Biology and new technology. J Craniofac Surg 2005;16:1043-54.

[40] Drengk A, Zapf A, Stürmer EK, Stürmer KM, Frosch KH. Influence of platelet-rich plasma on chondrogenic differentiation and proliferationof chondrocytes and mesenchymal stem cells. Cells Tissues Organs 2009; 189:317-26.

[41] Castillo TN, Pouliot MA, Kim HJ, et al. Comparison of growth factor and platelet concentration from commercial platelet-rich plasma separation systems. Am J Sports Med. Feb 2011;39(2):266- 271. PMID 21051428

[42] Hsu WK, Mishra A, Rodeo SR, et al. Plateletrich plasma in orthopaedic applications: evidence- based recommendations for treatment. J Am Acad Orthop Surg. Dec 2013;21(12):739748. PMID 24292930

[43] Sampson S, Gerhardt M, Mandelaum B. Platelet rich plasma injection grafts for musculoskeletal injuries: A review. Curr Rev Musculoskelet Med 2008; 1:165-74.

[44] Hunziker EB, Driesang IM, Morris EA. Chondrogenesis in cartilage repair is induced by members of the transforming growth factor-beta superfamily. Clin Orthop Relat Res 2001;391(suppl):S171-81.

Citation: Alaa Ali M. Elzohry, Mohammed Farghaly Abd Elhamed, Bahaa Gamal Saad, Updates in Knee Joint Osteoarthritis, ARC Journal of Anesthesiology. 2019; 4(2): 1-6. doi:dx.doi.org/10.20431/2455-9792.0402001.

Copyright: () 2019 Authors. This is an open-access article distributed under the terms of the Creative Commons Attribution License, which permits unrestricted use, distribution, and reproduction in any medium, provided the original author and source are credited. 